\title{
Flower Abscission and Induction in North American Ginseng with Ethephon
}

\author{
Andrea E. Fiebig, J.T.A.Proctor, ${ }^{1}$ and D.P. Murr \\ Department of Plant Agriculture, University of Guelph, Guelph, Ontario, N1G \\ 2W1, Canada
}

\author{
R.D. Reeleder ${ }^{2}$ \\ Southern Crop Protection and Food Research Centre, Agriculture and Agri-Food \\ Canada, 1391 Sandford Street, London, Ontario, N5V 4T3, Canada
}

Additional index words. abscission, berry count, Panax quinquefolius, plant growth regulators, root weight

\begin{abstract}
Field experiments over 2 years were used to determine the effect of ethephon on: plant growth, weight of berries, proportion of red, green and immature berries, and root weight (economic yield) of 3-year-old north american ginseng plants (Panax quinquefolius L.). Ethephon sprays applied during bloom that thoroughly wetted the foliage and inflorescences immediately induced crop canopy descent (epinasty) exposing inflorescences and subsequently reducing plant height. Within a week the desired inflorescence and peduncle browning and flower drop took place. In each of four experiments ethephon, over the range 500 to $4000 \mathrm{mg} \cdot \mathrm{L}^{-1}$, reduced berry weight and percent red berries, and increased the percent immature berries linearly. However, the responses to ethephon were variable. The highest concentration of $4000 \mathrm{mg} \cdot \mathrm{L}^{-1}$ ethephon caused similar results in both years to the traditional practice of hand removal of inflorescences, but foliar reddening and some defoliation were observed. Buffering ethephon sprays at pH 2.6, 4.0, 5.0, and 6.0 gave similar results. The surfactant Tween 20 did not increase the effectiveness of the sprays. Generally, multiple applications of ethephon at lower concentrations were no more effective than comparable single higher concentration sprays. Carry-over effect of ethephon in the second year included crop stunting, an increase in root weight, and berry weights and berry color proportions similar to those plants on which hand removal was carried out in the first year. Chemical names used: 2-chloroethyl phosphonic acid (ethephon).
\end{abstract}

North American ginseng (Panax quinquefolius L.) is a slow-growing herbaceous perennial plant(Order, Umbellerales; Family,Araliaceae) that is native to eastern North America (Proctor and Bailey, 1987). Because of its highly valued root it has been harvested from its native habitat, the under-story of deciduous hardwood forests, since the 1700s and cultivated in Ontario, Canada, and Wisconsin, USA for more than 100 years (Proctor, 1996).

Ginseng was used primarily in South East Asia and Pacific Rim countries but is now gaining more extensive use due to its reported medicinal and herbal properties (But et al. 1995; Fulder, 1996). Lee (1992) reported that ginseng had adaptogenic, stimulating, anabolic, antibiotic and anticancer activities. The expanding use of ginseng in Western medicine has stimulated production in the two traditional North American areas of Ontario and Wisconsin, and a new area, British Columbia (Proctor, 1996; Proctor

Received for publication 4 May 2004. Accepted for publication 28 July 2004. This research was supported in part by the National Research Council, Industrial Research Assistance Program, Technical Enhancement Project 28317U (coordinatior, Bernie Schmidt, P Eng.), J.C.K. Farms and The Ginseng Growers Association of Canada. We are indebted to Dean Louttit, Annelle Mundt and Lindsay Park for technical assistance.

${ }^{1}$ To whom reprint requests should be addressed; e-mail jtprocto@uoguelph.ca. at al. 1999). In addition, cultivation outside of North America is being evaluated (Bailey and Proctor, 2003).

North American ginseng production has expanded rapidly in the last decade and returns on investment have decreased as crop values have declined and production costs increased. To remain profitable growers need new integrated crop management approaches, for reduced pesticide use and replacement of manual inflorescence removal at $\$ 2500$ per hectare with an inexpensive method in 2-, 3and 4-year-old ginseng. Proctor et al. (1999) showed that manual inflorescence removal in 3 -year-old ginseng increased root yield by $26 \%$ but labor costs were significant (\$2500/ha). Use of plant growth regulators (PGRs) to induce flower abscission may provide a less expensive method of increasing root yield.

Prior to the present study we had screened PGRs for flower abscission in ginseng. Some compounds, e.g., thidiazuron, were ineffective in flower abscission, but thickened roots, induced adventitious buds in the roots, and increased root yield (Proctor et al. 1996). Of the PGRs screened, ethephon showed promise for inducing flower abscission in ginseng. We have shown that the ginseng floret abscission zone and berry drop were stimulated by ethylene (Fiebig et al., 2001). The objective of this study was to evaluate ethephon in field experiments as a replacement for manual flower removal in ginseng.
Flower abscission experiments with ethephon were done on 3-year-old plants at the Delhi(Ont.) Research Farm of the Southern Crop Protection andFood Research Centre (Agriculture and AgriFood Canada) and at a commercial ginseng farm (J.C.K. Farms, Rice Farms) near Paris, Ont., in 1996 (year 1) and 1997 (year 2).

Plants were established at a seeding rate of $112 \mathrm{~kg} \cdot \mathrm{ha}^{-1}$ and grown using standard North American techniques and cultural methods (Proctor, 1996). Plants were grown on raised soil beds covered with 5 to $10 \mathrm{~cm}$ of straw mulch. Wooden lath shades were placed $2 \mathrm{~m}$ above the beds to reduce solar radiation to an optimal $15 \%$ to $25 \%$ of full sunlight. Standard commercial practices for pest control were followed (Ontario Ministry of Agriculture, Food and Rural Affairs, 1999).

Treatments consisted of a water-sprayed control, manual inflorescence removal (hand removal(HR), Proctor et al., 1999) and ethephon sprays (see below and Tables). Foliar sprays were applied with an $8.5 \mathrm{~L}$ Hudson backpack sprayer fitted with a Teejet nozzle (80015) at about $2 \mathrm{~kg} \cdot \mathrm{cm}^{-2}$ pressure until the foliage and inflorescence were thoroughly wetted. The estimated spray volumes of 1640 and $2786 \mathrm{~L} \cdot \mathrm{ha}^{-1}$ (applied at the Delhi and Rice sites, respectively) are higher than those $\left(700 \mathrm{~L} \cdot \mathrm{ha}^{-1}\right)$ used for many ginseng fungicide spray applications in Ontario (Oliver, 1998). About 0.3 L of solution was applied per plot at Delhi, whereas the Rice plots received $0.875 \mathrm{~L}$ of solution each, reflecting differences in plant population at the two sites (100.6 \pm 15.1 plants $/ \mathrm{m}$ of row at Delhi and 146.1 \pm 16.1 at the Rice site. Air temperature at the top of the plant canopy at treatment application time ranged from 19 to $25^{\circ} \mathrm{C}$.

Each treatment was replicated four times in a randomized complete block design with four blocks. The spray treatments applied on 4 July 1996 to 1-m plots of ginseng at the Delhi Research Station consisted of ethephon at 500, $1000,1500,2000,3000$, or $4000 \mathrm{mg} \cdot \mathrm{L}^{-1}$, as well as the aforementioned controls. Treatments in 1997 at Delhi took place on 8, 14, and 18 July, and included ethephon concentrations of 500 ( $\mathrm{X} 1=$ once, $\mathrm{X} 2=$ twice, $\mathrm{X} 3=$ thrice $), 750,1000$, $1250,1500,2000,3000$, and $4000 \mathrm{mg} \cdot \mathrm{L}^{-1} \cdot \mathrm{A}$ Tween 20 surfactant (polyoxyethylene sorbitan monolaurate) at 4 drops/L was evaluated at both the Delhi and Rice sites in 1997. Plots of ginseng $1.7 \mathrm{~m}$ long at Rice Farms received treatments to determine the effects of buffering and spray solution $\mathrm{pH}$. In 1996 spray treatments consisted of a citrate-phosphate buffer ( $\mathrm{pH} 2.6$ or 6.0) applied on 17 July, and multiple ethephon treatments at $1500 \mathrm{mg} \cdot \mathrm{L}^{-1}$ (applied either X1, X2, X3, X4 and at $\mathrm{pH} 2.6,4.0,5.0$, or 6.0), which were applied on 4, 11, 17, and 25 July. In 1997, Rice plots received treatments of ethephon at 1500,1000 (X1, X2, X3, X4), and $750(\mathrm{X} 1, \mathrm{X} 2, \mathrm{X} 3, \mathrm{X} 4)$ $\mathrm{mg} \cdot \mathrm{L}^{-1}$ on $9,14,18$, and 22 July. In both 1996 and 1997 all single applications were made on the first date listed and all second, third and fourth applications made on the second, third and fourth sequential dates as listed. The same water and manual removal controls were used at the Rice gardens as at Delhi. 
Visual observations of plant growth and injury were made during the growing season. Ginseng berries were harvested manually in early September (see Tables). Total plot berry weights and the proportion of red to green to immature berries were determined at the time of berry harvest. Roots were hand-dug in late September or early October of each year (see Tables), washed free of soil, and weighed.

Data were analysed using the General Linear Models (GLM) procedure of the Statistical Analysis System(SAS) program package (SAS Institute, Cary, N.C.). Data were subjected to orthogonal contrast analysis of linear and quadratic components of PGR concentration using GLM. Treatment means were compared at $P \leq 0.05$.

\section{Results and Discussion}

Plant response. Within 2 to $3 \mathrm{~d}$ after spraying with ethephon the canopy descended nearer to the horizontal plane, an epinastic effect and exposed the inflorescences. This morphological response is typical of ethylene exposure and has been reported for many crops and plants, e.g., for tomato by Woodrow et al. (1998). No injury to the ginseng plants was evident. However, a few weeks later, at the highest concentration of ethephon, yellowing and reddening of the leaves were observed. At the end of the growing season plants in some of the plots that had been sprayed with $4000 \mathrm{mg} \cdot \mathrm{L}^{-1}$ were completely defoliated. Within a week of application the desired inflorescence and peduncle browning, and flower shrivelling and dropping took place.

The higher concentrations of ethephon $(1500$ $\mathrm{mg} \cdot \mathrm{L}^{-1}$ and above), resulted in the greatest decreases in berry weight and were similar to the HR treatment (Table 1). Ethephon decreased total plot berry weights both linearly and curvilinearly with a linear dominance at the lower concentrations (Table 1). Most berries in the inflorescence were immature at harvest (Table 1). Ethephon treatments reduced the percent red berries and increased percent immature berries. Ethephon at 1500 to $4000 \mathrm{mg} \cdot \mathrm{L}^{-1}$ was similar to HR in decreasing the percent red berries (Table 1). Those inflorescences with lower percentages of red and higher percentages of immature would likely not be competing with the root for assimilates produced during the growing season as they were small.

Total plot berry weights at Delhi in 1997 were also reduced with increasing concentrations of ethephon (Table 2). The only treatments that were similar to HR were the highest ethephon treatments of 3000 and $4000 \mathrm{mg} \cdot \mathrm{L}^{-1}$. Multiple applications of $500 \mathrm{mg} \cdot \mathrm{L}^{-1}$ also decreased weights, similar to single applications (e.g., X2 ethephon at $500 \mathrm{mg} \cdot \mathrm{L}^{-1}$ resembled weights obtained by a single application of $\left.1000 \mathrm{mg} \cdot \mathrm{L}^{-1}\right)$.

At the Rice site in 1996 multiple applications of $1500 \mathrm{mg} \cdot \mathrm{L}^{-1}$ ethephon also reduced berry weights which were often similar to HR weights (Table 3). With increased ethephon applications, injury was more pronounced: reddening of the leaves, and browning and drying of the floral structure were observed throughout.

Application of citrate-phosphate buffer at two different $\mathrm{pHs}$ (2.6 and 6.0) resulted in berry weights that were either greater than, or equal to, the untreated control and were not considered further (data not shown). All plants treated with buffered ethephon remained green with only a slight reddening of the leaf blades away from the veins and had little effect on berry weight (Table 3). Because of this and no effect on root weight (see below), buffering ethephon had no advantage for application on ginseng and would only add additional cost to the cultivation of this crop. These findings support those of Denney and Martin (1994) for olive fruit removal and Olien and Bukovac (1978) for ethylene evolution in sour cherry leaves.

When the ethephon sprayed plots were evaluated visually at the end of the season the erratic response to ethephon was apparent. In many cases, plants treated with the highest concentrations of ethephon had less injury than some at the lower concentrations. There was still some reddening of the leaves and early ripening of the seed head, but the severity of the injury was less than seen in the previous year. Erratic responses to ethephon as an apple thinner have been reviewed by Marini (2004).

As the number of ethephon applications at both concentrations was increased berry weights were reduced linearly at the Rice site in 1997 (Table 4). As with the Delhi plots in 1997, the visual effects of the sprays on the plants were not consistent in the field or with what was seen in the preceding year. More injury was not always seen for the applications of 1000 $\mathrm{mg} \cdot \mathrm{L}^{-1}$ when compared to $750 \mathrm{mg} \cdot \mathrm{L}^{-1}$, and the multiple applications did not have increased injury. Red leaves, ripening berries, and drying of the inflorescence were still seen, although not

Table 1. Effect of ethephon on north american ginseng berry weight, berry color, and root fresh weight. Treatments were applied on 4 July 1996 to Delhi garden plots.

\begin{tabular}{|c|c|c|c|c|c|}
\hline \multirow[b]{2}{*}{ Treatment } & \multirow{2}{*}{$\begin{array}{c}\text { Berry wt }{ }^{z} \\
(\mathrm{~g} / \mathrm{plot})\end{array}$} & \multicolumn{3}{|c|}{ Berry color $(\%)$} & \multirow{2}{*}{$\begin{array}{l}\text { Root fresh wt } \\
\text { (g/root) }\end{array}$} \\
\hline & & Red & Green & Immature & \\
\hline \multicolumn{6}{|c|}{ Ethephon (mg. $\left.\mathrm{L}^{-1}\right)$} \\
\hline 0 & 97.58 & 14.35 & 3.28 & 80.67 & 9.99 \\
\hline 500 & 62.50 & 14.14 & 7.60 & 74.56 & 11.14HR \\
\hline 1000 & $19.10 \mathrm{HR}^{\mathrm{y}}$ & 4.84 & 1.99 & 90.14 & $12.48 \mathrm{HR}$ \\
\hline 1500 & $5.13 \mathrm{HR}$ & $2.16 \mathrm{HR}$ & 3.24 & 94.60 & $11.94 \mathrm{HR}$ \\
\hline 2000 & $4.58 \mathrm{HR}$ & $0.63 \mathrm{HR}$ & 6.07 & 93.31 & $10.88 \mathrm{HR}$ \\
\hline 3000 & $2.43 \mathrm{HR}$ & $3.45 \mathrm{HR}$ & 5.06 & 89.05 & 10.41 \\
\hline 4000 & $0.15 \mathrm{HR}$ & $0.89 \mathrm{HR}$ & $1.74 \mathrm{HR}$ & 95.46 & 9.66 \\
\hline \multicolumn{6}{|l|}{ Significance $^{\mathrm{x}}$} \\
\hline $\mathrm{L}$ & $* * * *$ & $* * * *$ & NS & $* * * *$ & NS \\
\hline Q & $* * *$ & $* * *$ & NS & NS & $*$ \\
\hline Hand removal & 0 & 0 & 0 & 0 & 12.41 \\
\hline
\end{tabular}

${ }^{\mathrm{z}}$ Berries were harvested on 4 Sept. and roots on 25 Sept.

${ }^{y} \mathrm{HR}=$ effect similar to hand removal of flowers at $P \leq 0.05$.

${ }^{\mathrm{x}}$ Means analyzed by single degree of freedom contrasts.

NS,*,***,*****effect nonsignificant or significant at $P \leq 0.05,0.001$ or 0.0001 respectively; $\mathrm{L}=$ linear, $\mathrm{Q}=$ quadratic.

Table 2. Effect of ethephon at various concentrations and multiple applications of $500 \mathrm{mg} \cdot \mathrm{L}^{-1} \mathrm{on}$ north american ginseng berry weight, plant height, and root fresh weight. Single treatments were applied on 8 July 1997 and multiple treatments were sprayed on 14 and 18 July 1997 to Delhi garden plots.

\begin{tabular}{lccc}
\hline Treatment & $\begin{array}{c}\text { Berry wt } \\
(\mathrm{g} / \mathrm{plot})\end{array}$ & $\begin{array}{c}\text { Plant ht in } \\
\text { August }(\mathrm{cm})\end{array}$ & $\begin{array}{c}\text { Root fresh } \\
\mathrm{wt}^{2}(\mathrm{~g} / \mathrm{root})\end{array}$ \\
\hline Ethephon $\left(\mathrm{mg} \cdot \mathrm{L}^{-1}\right)$ & 315.75 & 38.63 & 8.35 \\
0 & 259.75 & $41.95 \mathrm{HR}$ & 9.53 \\
500 & 168.00 & $40.30 \mathrm{HR}$ & $9.93 \mathrm{HR}$ \\
750 & 147.50 & $43.85 \mathrm{HR}$ & 9.26 \\
1000 & 143.75 & $42.60 \mathrm{HR}$ & $9.91 \mathrm{HR}$ \\
1250 & 103.25 & $43.80 \mathrm{HR}$ & $9.61 \mathrm{HR}$ \\
1500 & 93.25 & $41.45 \mathrm{HR}$ & $9.68 \mathrm{HR}$ \\
2000 & $47.25 \mathrm{HR}$ & 9.37 \\
3000 & $40.25 \mathrm{HR}$ & $43.88 \mathrm{HR}$ & 8.22 \\
4000 & & 40.23 & $\mathrm{NS}$ \\
Significance & $* * * *$ & & $*$ \\
L & NS & NS & 8.35 \\
Q & & & 9.53 \\
Ethephon $\left(500 \mathrm{mg}^{\mathrm{x}} \mathrm{L}^{-1}\right)^{\mathrm{w}}$ & 315.75 & 38.63 & 8.81 \\
0 & 259.75 & $41.95 \mathrm{HR}$ & 8.08 \\
X1 & 143.75 & $43.00 \mathrm{HR}$ & $\mathrm{NS}$ \\
X2 & 68.50 & $42.83 \mathrm{HR}$ & $\mathrm{NS}$ \\
X3 & & & 11.07 \\
Significance & $* * * *$ & $\mathrm{NS}$ & $\mathrm{NS}$ \\
L & $* * *$ & 44.70 & \\
Q & 0 & &
\end{tabular}

${ }^{\mathrm{z} B e r r i e s}$ were harvested on 4 Sept. and roots on 1 Oct.

${ }^{\mathrm{y}} \mathrm{HR}=$ effect similar to hand removal of flowers at $P \leq 0.05$.

${ }^{x}$ Means analyzed by single degree of freedom contrasts.

${ }^{\mathrm{w}}$ Multiple applications $(\mathrm{X} 1=$ once, $\mathrm{X} 2=$ twice, $\mathrm{X} 3=$ thrice $)$ or $500 \mathrm{mg} \cdot \mathrm{L}^{-1}$ ethephon.

NS,*,**,*****Effect not significant or significant at $P \leq 0.05,0.001$ or 0.0001 respectively; $\mathrm{L}=$ linear, $\mathrm{Q}=$ quadratic. 
Table 3. Effect of multiple applications of ethephon at $1500 \mathrm{mg} \cdot \mathrm{L}^{-1}$ on north american ginseng berry weight. Multiple ethephon sprays were applied on 4, 11, 17, and 25 July 1996 and buffered ethephon treatments were applied on 17 July 1996 to Rice garden plots.

\begin{tabular}{lc}
\hline Treatment & $\begin{array}{c}\text { Berry wt } \\
(\mathrm{g} / \mathrm{plot})\end{array}$ \\
\hline Ethephon $\left(\mathrm{mg} \cdot \mathrm{L}^{-1}\right)^{y}$ & \\
0 & 239.81 \\
$\mathrm{X} 1$ & 134.83 \\
X2 & $21.15 \mathrm{HR}^{\mathrm{x}}$ \\
X3 & $5.05 \mathrm{HR}$ \\
X4 & $0.50 \mathrm{HR}$ \\
Significance & \\
L & $* * * *$ \\
Q & $* * *$ \\
Hand removal & 0 \\
Buffered & \\
pH 2.6 & 102.47 \\
pH 4.0 & 80.95 \\
pH5.0 & 100.55 \\
pH 6.0 & 89.33 \\
Significance & \\
L & $* * * *$ \\
Q & $* * *$ \\
Hand removal & 0 \\
\hline
\end{tabular}

${ }^{2}$ Berries were harvested on 4 Sept.

${ }^{\mathrm{y}} 1500 \mathrm{mg} \cdot \mathrm{L}^{-1}$ ethephon applied at different times (X1 = once, $\mathrm{X} 2$ = twice, $\mathrm{X} 3=$ thrice) and $1500 \mathrm{mg} \cdot \mathrm{L}^{-1}$ ethephon buffered with a citrate-phosphate buffer.

${ }^{x} \mathrm{HR}=$ effect similar to hand removal of flowers at $P \leq 0.05$.

"Means analyzed by single degree of freedom contrasts.

NS, ,****,**** Effect not significant or significant at $P \leq$ $0.05,0.001$ or 0.0001 respectively; $\mathrm{L}=$ linear, $\mathrm{Q}$ $=$ quadratic.

to the degree observed in 1996. Only one of the treatments gave results similar to HR.

Since this project ran for 2 years, it was possible to study carry-over effects on 4-year-old plants that had been treated the previous year.
The plants that had been sprayed the previous year were healthy throughout the following growing season and matured similarly to the controls that had not been sprayed and those that had been manually deflowered. Total plot berry weights showed that, even in the following year, increasing ethephon treatments from 500 to 4000 $\mathrm{mg} \cdot \mathrm{L}^{-1}$ decreased the weights linearly (Table 5). There was no significance of treatment on berry color (Table 5). All seed heads were allowed to set seed in 1997, so it is not surprising that all treatments were similar to HR, for all types of berries. Therefore, it is recommended that spraying with ethephon at these concentrations to remove inflorescences be done in the summer of the same year as rootharvest, especially if the grower plans to use the seeds or berries for propagation in the following growing season.

In 1996, the treatment(s) that gave the best results for ginseng berry removal, considering as well the foliar injury, were single applications of $1500 \mathrm{mg} \cdot \mathrm{L}^{-1}$ or a double treatment with 1500 $\mathrm{mg} \cdot \mathrm{L}^{-1}$. The following year, a wider range of concentrations were studied. Unfortunately, the results obtained at the end of this season were more erratic than those found in the first year. This variability was expected, since ethephon is affected by environmental factors such as light (Greene, 1996), temperature (Lavee and Martin, 1981b; Olien and Bukovac, 1982), and application time (Denney and Martin, 1994). Care was taken at the time of spraying to minimize these variables, but many of these factors were not controllable.At the Delhi site the only treatments that showed any similarity were the highest concentrations of ethephon (3000 and 4000 $\left.\mathrm{mg} \cdot \mathrm{L}^{-1}\right)$. With the variability seen in the ethephon treatments, rate recommendation becomes difficult. The results demonstrated that although some treatments were not as good as HR, they may still be able to remove high percentages of

Table 4. Effect of treatment with multiple applications of ethephon at 750 and $1000 \mathrm{mg} \cdot \mathrm{L}^{-1} \mathrm{on}$ north american ginseng berry weight, plant height, and root fresh weight. Treatments were applied on 9, 14, 18 , and 22 July 1997 to Rice garden plots.

\begin{tabular}{|c|c|c|c|}
\hline Treatment & $\begin{array}{c}\text { Berry wt }{ }^{z} \\
(\mathrm{~g} / \mathrm{plot})\end{array}$ & $\begin{array}{c}\text { Plant ht in } \\
\text { August }(\mathrm{cm})\end{array}$ & $\begin{array}{c}\text { Root fresh } \\
\mathrm{wt}^{\mathrm{z}} \text { (g/root) }\end{array}$ \\
\hline \multicolumn{4}{|c|}{ Ethephon $\left(750 \mathrm{mg} \cdot \mathrm{L}^{-1}\right)^{y}$} \\
\hline 0 & 561.50 & 47.25 & 11.95 \\
\hline $\mathrm{X} 1$ & 294.50 & $48.50 \mathrm{HR}^{\mathrm{x}}$ & 12.76 \\
\hline $\mathrm{X} 2$ & 304.50 & $50.75 \mathrm{HR}$ & 12.62 \\
\hline $\mathrm{X} 3$ & 193.75 & $47.50 \mathrm{HR}$ & 13.77HR \\
\hline $\mathrm{X} 4$ & 139.00 & $45.50 \mathrm{HR}$ & 12.90 \\
\hline \multicolumn{4}{|l|}{ Significance $^{\mathrm{w}}$} \\
\hline $\mathrm{L}$ & $* * * * \mathrm{~d}$ & NS & NS \\
\hline Q & NS & $*$ & $*$ \\
\hline \multicolumn{4}{|c|}{ Ethephon $\left(500 \mathrm{mg} \cdot \mathrm{L}^{-1}\right)^{\mathrm{y}}$} \\
\hline 0 & 561.50 & 47.25 & 11.95 \\
\hline $\mathrm{X} 1$ & 301.00 & $45.00 \mathrm{HR}$ & $13.90 \mathrm{HR}$ \\
\hline $\mathrm{X} 2$ & 278.25 & $47.25 \mathrm{HR}$ & 12.43 \\
\hline $\mathrm{X} 3$ & 140.00 & $46.50 \mathrm{HR}$ & 13.15 \\
\hline $\mathrm{X} 4$ & $48.50 \mathrm{HR}$ & $47.25 \mathrm{HR}$ & 12.47 \\
\hline \multicolumn{4}{|l|}{ Significance } \\
\hline $\mathrm{L}$ & $* * * *$ & NS & NS \\
\hline Q & NS & NS & NS \\
\hline Hand removal & 0 & 47.75 & 14.63 \\
\hline
\end{tabular}

${ }^{\mathrm{z} B e r r i e s}$ were harvested on 3 Sept. and roots on 30 Sept.

${ }^{y}$ Multiple applications of ethephon $(\mathrm{X} 1=$ once, $\mathrm{X} 2=$ twice, $\mathrm{X} 3=$ thrice $)$ at 750 and $1000 \mathrm{mg} \cdot \mathrm{L}^{-1}$, respectively.

${ }^{x} \mathrm{HR}=$ effect similar to hand removal of flowers at $P \leq 0.05$.

${ }^{\text {w}}$ Means analyzed by single degree of freedom contrasts.

NS,*,***,***** Effect nonsignificant or significant at $P \leq 0.05,0.001$ or 0.0001 respectively; $\mathrm{L}=$ linear, $\mathrm{Q}=$ quadratic. berries from ginseng inflorescences.

Rootfreshweight (economic yield) and plant height. The water sprayed control had a mean root weight of $9.99 \mathrm{~g}$ and the HR $12.41 \mathrm{~g}$ (Table 1), paralleling the increase (26\%) determined by Proctor et al. (1999). Ethephon at 500 to 2000 $\mathrm{mg} \cdot \mathrm{L}^{-1}$ gave similar results to the HR treatment. Results from the highest concentrations of ethephon (3000 and $4000 \mathrm{mg} \cdot \mathrm{L}^{-1}$ ) sprayed at this site were not as good as results from HR, even though they were the most successful treatment at removing the inflorescences. Jones et al. (1989) and Marini (2004) reported that the concentration of ethephon, date of application, cultivar differences, temperature variation, blossom density and spray volume contributed to the variable results obtained when ethephon was sprayed at bloom time as a chemical thinner for apples. Some of these factors could apply to ginseng; other things may also apply. For instance, north american ginseng is an undomesticated crop, genetically diverse with no registered cultivars or improved populations (Boehmet al., 1999).Also, ginseng flowers over a 6-week period (Fiebig et al., 2001) and flower abscission may vary with time.

The root fresh weights obtained from plots treated with the buffer at a $\mathrm{pH}$ of 2.6 and 6.0 were 12.25 and $12.04 \mathrm{~g} /$ root respectively, and were not different from the untreated control that had a root weight of $12.71 \mathrm{~g} /$ root. There were no significant relationships between the number of applications, buffering or the $\mathrm{pH}$ of the ethephon solution and the root fresh weight (data not shown).

In 1996 plant height differences were observed: plants treated with ethephon were stunted, particularly at $4000 \mathrm{mg} \cdot \mathrm{L}^{-1}$. In 1997 there was a quadratic relationship between ethephon concentration and plant height (Table 2); maximal values were around $1000 \mathrm{mg} \cdot \mathrm{L}^{-1}$. The multiple treatments of $500 \mathrm{mg} \cdot \mathrm{L}^{-1}$ had no effect on plant height.

The untreated control at Delhi in 1997 had a root weight of $8.35 \mathrm{~g}$ compared to $11.07 \mathrm{~g}$ (Table 2) for HR, an increase of $32.6 \%$ and surpassing the $26 \%$ yield increase reported by Proctor et al. (1999). The single applications from 0 to $4000 \mathrm{mg} \cdot \mathrm{L}^{-1}$ ethephon resulted in a quadratic effect with maximal values of about $1250 \mathrm{mg} \cdot \mathrm{L}^{-1}$. The multiple applications of 500 $\mathrm{mg} \cdot \mathrm{L}^{-1}$ had no effect on the root weight. Addition of Tween 20 to the ethephon solutions to aid with spreading the solution gave results similar to HR. This finding that the surfactant had an effect on the plants would indicate that it was having a biological effect on ginseng and it could also contribute to the erratic effects seen in the second year of the study. The omission of surfactant in 1996 provided better results than those with the wetter, and leads to the conclusion that a spreader may not be necessary in ginseng production practices. At the Rice site Tween 20 treatment was the same as the controls (data not shown).

Hand removal at the Rice site increased root weight from 11.95 to $14.63 \mathrm{~g} /$ root, a $22.4 \%$ increase (Table 4). Ethephon sprays at 750 $\mathrm{mg} \cdot \mathrm{L}^{-1}$ applied 3 times, and at $1000 \mathrm{mg} \cdot \mathrm{L}^{-1}$ applied once, and three times, gave root weight values similar to $\mathrm{HR}$. 
Table 5. Residual effect of ethephon on north american ginseng berry weight, berry color, plant count, plant height, and root fresh weight. Treatments were applied on 4 July 1996 to Delhi garden plots. Measurements were taken in Fall 1997.

\begin{tabular}{|c|c|c|c|c|c|c|c|c|}
\hline \multirow[b]{2}{*}{ Treatment } & \multirow{2}{*}{$\begin{array}{l}\text { Berry } \\
w^{2} \\
(g / p l o t)\end{array}$} & \multicolumn{3}{|c|}{$\begin{array}{l}\text { Berry } \\
\text { color } \\
(\%)\end{array}$} & \multirow{2}{*}{$\begin{array}{c}\text { Plant } \\
\text { count } \\
\text { (no./plot) }\end{array}$} & \multicolumn{2}{|c|}{$\begin{array}{c}\text { Plant } \\
\mathrm{ht}(\mathrm{cm})\end{array}$} & \multirow{2}{*}{$\begin{array}{c}\text { Root } \\
\text { fresh wt }{ }^{2} \\
(\mathrm{~g} / \text { root })\end{array}$} \\
\hline & & Red & Green & Immature & & June & August & \\
\hline 500 & 207.13 & $37.13 \mathrm{HR}^{y}$ & $12.94 \mathrm{HR}$ & 49.93HR & $96.00 \mathrm{HR}$ & $37.50 \mathrm{HR}$ & $40.65 \mathrm{HR}$ & 16.37HR \\
\hline 1000 & 212.73 & $48.63 \mathrm{HR}$ & $10.24 \mathrm{HR}$ & 41.14HR & $98.50 \mathrm{HR}$ & $34.25 \mathrm{HR}$ & $38.18 \mathrm{HR}$ & 19.27 \\
\hline 1500 & 179.10 & $34.02 \mathrm{HR}$ & 17.18 & 48.48HR & 106.75HR & 33.00 & $39.30 \mathrm{HR}$ & 18.90 \\
\hline 4000 & 130.48 & $30.10 \mathrm{HR}$ & $15.47 \mathrm{HR}$ & $54.42 \mathrm{HR}$ & $99.00 \mathrm{HR}$ & 27.13 & $35.30 \mathrm{HR}$ & 18.92 \\
\hline \multicolumn{9}{|l|}{ Significance $^{x}$} \\
\hline $\mathrm{L}$ & $* * * *$ & NS & NS & NS & NS & $* * * *$ & $*$ & * \\
\hline Q & NS & NS & NS & NS & NS & NS & NS & $*$ \\
\hline Hand removal in 1996 & 277.65 & 40.38 & 9.01 & 50.31 & 107.50 & 38.34 & 37.95 & 15.63 \\
\hline
\end{tabular}

${ }^{2}$ Berries were harvested on 4 Sept. and roots on 1 Oct.

${ }^{\mathrm{y}} \mathrm{HR}=$ effect similar to hand removal of flowers at $P \leq 0.05$.

${ }^{x}$ Means analyzed by single degree of freedom contrasts.

NS,",*****Effect not significant or significant at $P \leq 0.05$ or 0.001 respectively; $\mathrm{L}=$ linear, $\mathrm{Q}=$ quadratic.

Analysis of residual ethephon effects was possible in 1997 because not all the 3-year-old plants at the Delhi site were harvested at the end of the 1996 growing season. All of the treatments had similar plant counts at the beginning of the 1997 season, even though some of the plots (e.g., ethephon at $4000 \mathrm{mg} \cdot \mathrm{L}^{-1}$ ) had extensive foliar damage in the previous year (Table 5). Plant height measurements in June and August showed that there was a residual height reduction from ethephon which increased with concentration (Table 5). Also, the inflorescences were narrower, and contained fewer flowers. With the perennating bud forming in 1996 for growth in 1997, exposure to the chemicals sprayed on the plant through translocation was highly probable (Davies, 1995).

Ethephon applied in 1996 increased root yield in 1997 (Table 5). These findings would suggest that the deleterious effects seen on the ginseng plots after spraying with ethephon are somehow overcome by the plants in the following year.

In summary, single applications of ethephon provided the best results, when all parameters were considered. This is the first report of the use of a PGR to thin ginseng flowers. Concentrations of 750 to $1500 \mathrm{mg} \cdot \mathrm{L}^{-1}$ of ethephon were consistently successful in the experiments carried out over the two year period, achieving flower abscission and obtaining the desired root weight increase. However, response to applied ethephon was variable as found for other crops (Jones et al., 1989; Marini, 2004; Turnbull et al., 1999). In other studies the optimum concentration of ethephon to achieve desired results varied with the species and the plant organ being affected. Nichols (1971) demonstrated that carnation petals required ethephon at $100 \mathrm{mg} \cdot \mathrm{L}^{-1}$ to abscise. Ethephon at $250 \mathrm{mg} \cdot \mathrm{L}^{-1}$ promoted abscission of sour cherry fruit (Olien and Bukovac, 1982) although response varied with application temperature. A decrease in water uptake after treatment with ethephon may be responsible for the phytotoxic effects seen in olive (Weis et al., 1988). All of these investigations dealt with plants whose economic return is in the aboveground portions of the plant: petals, fruit, leaves, etc. When the root is the economic yield, as in ginseng, the application of PGRs is complicated. Application of any PGR to root crops has to affect the root indirectly since spray application during the growing season is absorbed through the foliage and translocated to the root. For ginseng, Proctor et al. (1996) showed that foliar sprays of thidiazuron thickened roots, induced adventitious buds in the roots, and increased root yield. Ethephon is not translocated once absorbed into the leaf (Lavee and Martin, 1981a). Instead, it is broken down into ethylene in the cells as it is absorbed and then this gas diffuses through the plant (Davies, 1995). The mechanism by which ethylene produces a biological response is not completely understood: it provides an exciting area for further study to improve our ability to manipulate crops. Control of, or reduction in, the variability in response to applied ethephon on ginseng is the next step in the search for a suitable material for flower removal.

\section{Literature Cited}

Bailey, W.G. and J.T.A. Proctor. 2003. The globalization of ginseng. Acta Hort. 620:427-451.

Boehm, C.L., H.C. Harrison, G. Jung, and J. Nienhuis. 1999 Organization of American and Asian ginseng germplasm using randomly amplified polymorphic DNA (RAPD) markers. J. Amer. Soc. Hort. Sci. 124:252-256.

But P.P.H., S.Y. Hu, and H. Cao. 1995. The ginseng plant: products and quality, p. 24-34. In: W.G. Bailey, C. Whitehead, J.T.A. Proctor, and J.T. Kyle (eds.). The challenges of the $21^{\text {st }}$ century.Proc. Intl. Ginseng Conf. Vancouver, Canada. 1994. Simon Fraser Univ. Press, Burnaby, BC, Canada.

Davies, P.J. 1995. The plant hormones; their nature, occurrence, and functions, p. 1-38. In: P.J. Davies (ed.). Plant hormones: Physiology, biochemistry and molecular biology. $2^{\text {nd }}$ ed. Kluwer, the Netherlands.

Denney, J. and G. Martin. 1994. Ethephon tissue penetration and harvest effectiveness in olive as a function of solution $\mathrm{pH}$, application time, and BA or NAA addition. J. Amer. Soc. Hort. Sci. 119:1185-1192.

Fiebig A.E., J.T.A. Proctor,U.Posluszny, and D.P. Murr. 2001 The north american ginseng inflorescence: Development, floret abscission zone and the effect of ethylene. Can. J. Bot. 79:1048-1056.

Fulder, S. 1996. The ginseng book: Nature's ancient healer. Avery Publ. Group, Garden City Park, N.Y.

Greene,D.W. 1996. Ethylene-based preharvest growth regulators, p. 149-159. In: K. Maib, K.P. Andrews, G. Lang, and K. Mullinix (eds.). Tree fruit physiology: Growth and development. Good Fruit Grower, Yakima, Wash.

Jones, K.M., T.B. Koen, M.J.Oakford, and S.A. Bound. 1989. Thinning 'Red Fuji' apples with ethephon or NAA. J. Hort. Sci. 64:527-532.
Lavee, S. and G. Martin. 1981a. In vitro studies on ethephon-induced abscission in olive. I. The effect of application period and concentration on uptake, ethylene evolution, and leaf abscission. J. Amer. Soc. Hort. Sci. 106:14-18.

Lavee, S. and G. Martin. 1981b. In vitro studies on ethephoninduced abscission in olive. II. The relation between ethylene evolution and abscission of various organs. J. Amer. Soc. Hort. Sci. 106:19-26.

Lee, F.C. 1992. Facts about ginseng, the elixir of life. Hollyn International Corporation, Elizabeth, N.J.

Marini, R.P. 2004. Combinations of ethephon and accel for thinning 'Delicious' apple trees. J. Amer. Soc. Hort. Sci. 129:175-181.

Nichols, R. 1971. Induction of flower senescence and gynaecium development in the carnation (Dianthus caryophyllus) by ethylene and 2-chloroethylphosphonic acid. J. Hort. Sci. 46:323-332.

Olien, W. and M. Bukovac. 1978. The effect of temperature on rate of ethylene evolution from ethephon and from ethephon-treated leaves of sour cherry. J. Amer. Soc. Hort. Sci. 103:199-202.

Olien, W. and M. Bukovac. 1982. Ethylene generation, temperature responses, and relative biological activities of several compounds with potential for promoting abscission of sour cherry fruit. J. Amer. Soc. Hort. Sci. 107:1085-1089.

Oliver, A. 1998. Ginseng production guide for commercial growers. Assn. Ginseng Growers of British Columbia (BC) and BC Min. Agr. Fisheries and Food, Victoria.

Ontario Ministry of Agriculture, Food and Rural Affairs.1999. 1999-2000 Ginseng pest control recommendations. Ont. Min. Agr. Publ. 610

Proctor, J.T.A. 1996. Ginseng: old crop, new directions, p. 565-577. In: J. Janick (ed.). Progress in new crops. Proc. $3^{\text {rd }}$ Natl.Symp. New crops: new opportunities, new technologies. ASHS Press, Alex., Va.

Proctor, J.T.A. andW. Bailey. 1987. Ginseng: Industry, botany, and culture. Hort. Rev. 9:188-236.

Proctor, J.T.A., T. Slimmon, and P. Saxena. 1996. Modulation of root growth and organogenesis in thidiazurontreated ginseng (Panax quinquefolium $\mathrm{L}$.). Plant Growth Regulat. 5:1-8.

Proctor, J.T.A., D.C. Percival, and D. Louttit. 1999. Inflorescence removal affects root yield of American ginseng. HortScience 34:82-84

Turnbull, C.G.N., E.R. Sinclair, K.L. Anderson, R.J. Nissen, A.J.Shorter, and T.E. Lanham. 1999. Routes of ethephon uptake in pineapple (Ananas italico comosus) and reasons for failure of flower induction. J. Plant Growth Regulat. 18:145-152.

Weis, K., R. Goren, G. Martin, and B. Webster. 1988. Leaf and inflorescence abscission in olive. I. Regulation by ethylene and ethephon. Bot. Gaz. 149:391-397.

Woodrow, L., R.G. Thompson, and B.Grodzinski. 1998. Effects of ethylene on photosynthesis and partitioning in tomato, Lycopersicon esculentum Mill. J. Expt. Bot. 39:667-684. 